\title{
Vi trenger en ny type henvisninger
}

\author{
Den elektroniske henvisningen brukes i dag til forespørsler, for å gi enkle beskjeder og for å stille spørsmål. \\ Vi trenger å skille mellom henvisning for et avklart medisinsk problem, for et uavklart problem, for delt \\ ansvar for en komplisert problemstilling og en forespørsel som ikke krever undersøkelse av pasienten. \\ En presisering av type henvisning kan gjøre henvisningsprosessen enklere for både sender og mottaker.
}

Allmennleger er blitt kritisert for å sende for mange og til dels unødvendige henvisninger (1). Henvisningsratene varierer betydelig fra lege til lege, og grunnene til dette er mange (2). Usikkerhet hos mindre erfarne leger kombinert med påtrykk fra pasientene om å bli henvist er trolig viktige årsaker (3).

Henvisninger fra allmennleger omfatter alt fra bestilling av en behandling eller en spesialundersøkelse som allmennlegen ikke selv kan utføre via etterlysning av råd vedrørende en vanskelig klinisk problemstilling til ønsket om å dele ansvaret med spesialisthelsetjenesten når det dreier seg om kompliserte medisinske problemstillinger (3). Imidlertid fremstår flere henvisninger mest som en beskrivelse av en pasient og en klinisk situasjon - bestillingen kommer ikke klart frem (4).

Ifølge pasient- og brukerrettighetsloven $\S$ 2-2 skal spesialisthelsetjenesten innen ti dager vurdere henvisningen og fastsette når helsehjelpen senest skal starte. Den korte vurderingsfristen har i praksis begrenset muligheten for å innhente supplerende opplysninger. Kvaliteten på henvisningen har derfor fătt større betydning for vurdering av og avgjørelse om pasienten har rett til helsehjelp og hva slags hjelp som skal tilbys.

En god henvisning gjør mottageren i stand til å se den samme medisinske problemstilling som senderen opplever $(1,5)$. Henvisningstypen «pakkeforløp kreft» har gitt fastlegene større ansvar for at de pasientene som trenger hjelp raskt, făr denne hjelpen innen den sykdomsspesifikke fristen på to uker. Ordningen sikrer at pasientene ikke blir skadelidende på grunn av manglende kvalitet på henvisningen og med det sykehuslegens oppfattelse av alvorlighetsgraden.

Pasientrettighetsloven (6) beskriver hva som skal til for at pasienten gis rett til behandling av en avklart tilstand eller utredning av en uavklart tilstand. I begge tilfeller skal det settes en frist for å starte helsehjelp. Bedre henvisninger vil trolig kunne redusere risikoen for feilprioriteringer. Myndighetene bør legge til rette for at henviser kan beskrive tilstanden og formålet på en mer presis måte. Men hvordan?

Vi tror at mange problemstillinger som kunne vært løst på annet vis, i dag håndteres ved å sende en henvisning. For eksempel brukes i dag henvisningsformatet til å etterlyse epikriser, til purring på manglende beskjed til pasienten om ventetid på sykehusbehandling eller til regulære klager på behandling i spesialisthelsetjenesten.
Trolig fører det at sykehusspesialistene ikke alltid er tilgjengelige på telefon når fastlegene trenger et råd vedrørende en vanskelig medisinsk problemstilling, til at fastlegene bruker det ene virkemidlet de rår over - nemlig henvisningen.

Det arbeides med å utvikle elektroniske beslutningsstøtteverktøy for å bedre kommunikasjonen mellom fastleger og sykehus $(7,8)$. Legeforeningen har pekt på at utvikling av elektroniske dialogmeldinger mellom fastlege og spesialist må virkeliggjøres

\section{«Vi tror at mange problemstillinger som kunne vært løst på annet vis, i dag hånd- teres ved å sende en} henvisning»

og samarbeider med Direktoratet for e-helse om elektronisk pasientjournal. Denne metodikken kan også brukes når pasientens fastlege har behov for å etterspørre tilleggsinformasjon til epikriser (9) eller når sykehusspesialisten har behov for å be om utfyllende informasjon om henvisningen.

En presisering av type henvisning kan gjøre henvisningsprosessen enklere for både sender og mottaker. Kategoriene kan være: henvisning til behandling (avklart medisinsk problem), henvisning til vurdering (uavklart medisinsk problem), delt ansvar for en komplisert medisinsk problemstilling eller forespørsel som ikke krever undersøkelse av pasienten.

\section{Olav Thorsen}

othorsen@lyse.net

Miriam Hartveit

Jan Emil Kristoffersen

Per Arne Holman

Olav Thorsen (f. 1949) er ph.d., spesialist i allmennmedisin, spesialistveileder, overlege i Stavanger kommune, forsker og leder for praksiskonsulentordningen ved Stavanger universitetssjukehus.

Forfatter har fylt ut ICMJE-skjemaet og oppgir ingen interessekonflikter.
Miriam Hartveit (f. 1972) er ph.d. og forsker ved Helse Fonna med hovedoppgave samhandlingsforskning mellom fastleger og spesialisert psykisk helsevern og forskning på kvalitetsforbedring i helsetjenesten.

Forfatter har fylt ut ICMJE-skjemaet og oppgir ingen interessekonflikter.

Jan Emil Kristoffersen (f. 1953) er tidligere fastlege og leder for Allmennlegeforeningen, nå fagsjef i Den norske legeforening med ansvar for primærhelsetjeneste, forebyggende helsearbeid og Helse-IKT

Forfatter har fylt ut ICMJE-skjemaet og oppgir ingen interessekonflikter.

Per Arne Holman (f. 1964) har en mastergrad $i$ helseledelse og helseøkonomi og er analyseog kvalitetssjef ved Lovisenberg Diakonale Sykehus.

Forfatter har fylt ut ICMJE-skjemaet og oppgir ingen interessekonflikter.

Litteratur

1. Thorsen O, Hartveit M, Baerheim A. The consultants' role in the referring process with general practitioners: partners or adjudicators? a qualitative study. BMC Fam Pract 2013; 14: 153.

2. Thorsen O, Hartveit M, Johannessen JO et al. Typologies in GPs' referral practice. BMC Fam Pract 2016; 17: 76.

3. Thorsen O, Hartveit M, Baerheim A. General prac titioners' reflections on referring: an asymmetric or non-dialogical process? Scand J Prim Health Care 2012; 30: 241-6.

4. Martinussen PE. Referral quality and the cooperation between hospital physicians and general practice: the role of physician and primary care factors. Scand J Public Health 2013; 41: 874-82.

5. Holman PA, Ruud T, Grepperud S. Horizontal equity and mental health care: a study of priority ratings by clinicians and teams at outpatient clinics. BMC Health Serv Res 2012; 12: 162.

6. Lov om pasient- og brukerrettigheter (pasientog brukerrettighetsloven). LOV-2015-12-11-97. https://lovdata.no/dokument/NL/lov/ 1999-07-02-63 (23.3.2017)

7. Rokstad IS, Rokstad KS, Holmen S et al. Electronic optional guidelines as a tool to improve the process of referring patients to specialized care: an intervention study. Scand J Prim Health Care 2013; 31: $166-71$

8. Heimly V. Electronic referrals in healthcare: a review. Stud Health Technol Inform 2009; 150: 327-31.

9. Kristoffersen JE, Gerner BH, Sundar T. Henvisningen - monolog eller dialog? Tidsskr Nor Legeforen 2012; 132: 802-3.

Mottatt 27.2. 2017, første revisjon innsendt 22.3. 2017, godkjent 23.3. 2017. Redaktør: Ketil Slagstad.

Publisert først på nett. 